\title{
Sentrum og snikksnakk Luther i bruk - i samfunn og skole
}

\begin{abstract}
Approaching the 500-year Reformation anniversary, the article discusses what might legitimize Luther as a topic in today's society and educational practice. Are his crucial ideas an exclusively religious heritage, or could they be converted to issues of common relevance? Referring to the ways Luther was used by the GDR state and church in the 1983 anniversary, the article questions the potential for recontextualizing his specifically theological issues. By this, it relates to a current debate in religion didactics whether stories could be taught according to their religiously specific or universal, existential dimensions - cf. the question of learning about or from religion. The cultural and political impact of Luther's theology obviously makes it relevant as common heritage. His theological issue, however - man's lack of free will (De servo arbitrio), and his view on «theological man» as defined solely by God's justification (De homine), which Luther considers to be his primary concern - appears to be counter-intuitive, i.e. different from what seems right or natural. Hence, it challenges the concept of cultural heritage, but proves a critical corrective to common, essentialist justifications of human dignity, cultural identity and superiority - which makes it an issue to be learnt from and not only about.
\end{abstract}

Emneord: Luther, reformasjonen, kulturarv, fagdidaktikk, religionsdidaktikk.

Av Per Anders Aas (f. 1956). Dr.art., førsteamanuensis ved Fakultet for lcererutdanning og internasjonale studier, Høgskolen i Oslo og Akershus. HiOA, Postboks 4 St. Olavs plass, o13o Oslo. E-post: peranders.aas@hioa.no

Luthers teser mot avlatshandelen 1517 regnes gjerne som reformasjonens utløsende årsak, og er utgangspunkt for 500-årsjubileet i 2017. Men hva gir grunn til feiring - og hvem tilhører feiringen? Utsagnene nedenfor handler begge om Luther-resepsjon, dvs. Luther $i$ bruk; det første stammer endog fra Luther selv:

[A]v samtlige er du den eneste som har gått løs på selve saken, på det som er kjernen $i$ hele konflikten, og ikke har kommet trekkende med alle disse andre spørsmålene som pavedømmet, skjærsilden, avlaten og den slags -slikt som er snikksnakk snarere enn seriøse spørsmål, men som nesten alle hittil har brukt for å få has på meg, til ingen nytte. Du og bare du har sett og siktet deg inn på selve sentrum og hovedsaken [...]. Luther til Desiderius Erasmus, Om den trellbundne viljen, 1525. (Luther 1981:351)

Det er, oss imellom sagt, ikke noe annet som er interessant ved det hele enn Luthers karakter, og den er også det eneste som virkelig gjør

\footnotetext{
1 Artikkelen bygger dels på et innlegg ved en workshop om fagdidaktikk for universitets- og høgskolelærere i religion, filosofi og etikk, arrangert av Nettverk for religion og livssyn, UiO 06.03.09. Tema var «Kunnskap i bruk», og mitt bidrag hadde tittelen «Om fagdidaktikk som innhold - ikke vedheng. Hvordan griper fagdidaktikken inn til - og former - kjernen i fagstoffet? Case: Luther-formidling i samfunn og skole».
} 
inntrykk på folk $i$ sin alminnelighet. Alt det andre er noe forvirret herk, slik det fremdeles daglig er til byrde for oss.

Goethe til Karl Ludwig von Knebel ved 300-årsfeiringen av teseoppslaget, 1817 . (Ebeling 1978:27)

Begge sitatene postulerer et sentrum som egentlig interessant, i motsetning til «alle disse andre spørsmålene», «alt det andre», som reduseres til irrelevant snikksnakk. Helt fra starten har man altså sett ulikt på hva reformasjonen handler om. Hva legitimerer så Luther som tema i samfunn og skole? Er «selve sentrum» en eksklusiv, indrekirkelig arv, eller kan - og bør - det rekontekstualiseres til et allment anliggende? Noe alle kan lære $a v$, og ikke bare om?

\section{KAIROS}

Luthers teologiske utgangspunkt, «Hvordan finne en nådig Gud?», er neppe felleseie i norsk nåtid. Det som forsvarer jubileet $\mathrm{i}$ offentligheten, er rimeligvis reformasjonens status som kulturarv - slik den også forsvarer Luthers plass i skolen. Da en K ble lagt til RLE i 2015, var det offisielt ikke for å styrke elevene som kristne, men som kulturarvinger.

Et jubileum er et kairos for kulturarv. Her aktualiseres budskapet som rette ord til rett tid. Slik blir kulturarven konstituert - ikke i fortida, men samtida. Filosofen Knut Ågotnes formulerer det slik:

Ein gjennomgåande synsmåte $i$ forskingslitteraturen om kulturarv er at dei perspektiv vi ser det fortidige ut frå, og dei kontekstar $v i$ set det inn $i, i$ prinsippet er samtidsbe- stemte. Forsking om kulturarv burde begynna i samtida - og innafor det fleirfaglege feltet heritage studies gjer den nettopp det. «Kulturarven» representerer kulturelle verdiar som er rådande $i$ samfunn og grupper. Det er ikkje dei objekt vi identifiserer som kulturarv som skaper desse verdiane, det er vi som har tilskrive dei våre verdiar. (Ågotnes 2008:9)²

En premissgiver i dette feltet er kulturgeografen David Lowenthal, som i boka The Past is a Foreign Country skiller mellom history som objektiv utforskning av fortida og heritage (kulturarv) som nåtidas interessebestemte aktualisering (Lowenthal 2015). Spørsmålet som legitimerer et jubileum, blir dermed ikke «Hva skjedde?», men «What's in it for me?». Også legitimert som kulturarv blir da enhver Luther-markering en verdimarkering.

Åtte år etter teseoppslaget lister altså Luther opp en serie topoi de fleste vil kjenne som sentrale i reformasjonen: «pavedømmet, skjærsilden, avlaten og den slags». Disse avviser han som snikksnakk. Alt her finner vi en spenning mellom intensjon og resepsjon; av en eller annen grunn har disse - ifølge Luther perifere - temaene matchet mottakernes interesser.

Den som vil bruke Luther i dag, må gå i dialog med kildene for å finne et sentrum som lar seg rekontekstualisere. Og siden konteksten er endret fra et religiøst til et sekulært samfunn, blir spørsmålet om det er mulig å aktualisere «selve saken». Reformasjonens kulturelle og politiske følger kan forsvare feiring. Men kan Luthers teologiske tema gjøres allment relevant? Og hvis man ikke gjør nettopp det, fremmer

\footnotetext{
2 Jf. Anne Eriksen om begrepsbruken: I UNESCOs konvensjon for beskyttelse av immateriell kulturarv heter det at kulturarven både overføres og stadig gjenskapes av fellesskap/grupper, og gir disse «a sense of identity and continuity». Fokus flyttes fra tingene til vårt forhold til dem, fra arven til arvingene (Eriksen 2009:478ff).
} 
man ikke da snikksnakk i stedet for sentrum?

Når kulturarv er definert ut fra bruksverdi, vil både jubileumsmarkering og kanonstatus være legitimert av et dobbelt formål: å lære om og lære av. I forhold til skole og fagdidaktikk er dette problematisk. Religions- og livssynsfaget skal ikke lenger fremme en religion - men skolen skal like fullt fremme verdier. Spørsmålet er om Luther representerer relevante verdier, eller om hans «reformatoriske oppdagelse» (en frigjøring av frustrerte kristne?) er så spesifikt teologisk og tidsbestemt at rekontekstualisering blir hermeneutisk tvilsomt.

På denne bakgrunn blir et jubileum også et kairos for fagdidaktikk. Da fagdidaktikken oppsto som forskningsfelt, var dens raison d'être framfor alt legitimeringsspørsmålet - fagets eller emnets hvorfor. Fagdidaktikk kan forstås som en måte å konstituere faget på, legitimert i en brukssituasjon. Målet med denne artikkelen er ut fra forståelsen av fagdidaktikk som faget/ emnet $i$ bruk - å unders $\emptyset$ ke muligheten for en Luther-aktualisering. Hvordan kan en fagdidaktisk tilnærming, hermeneutisk forsvarlig, sirkle inn et relevant sentrum? Og kan et slikt sentrum aktualiseres som et allment anliggende? Hvem har bruk for Luther?

Kirken er en åpenbar arving. Staten er ikke lenger luthersk, men bygger ifølge Grunnlovens §2 på kristne og humanistiske verdier, og kan identifisere seg med arven i den grad den samsvarer med en allmenn verdiforståelse. Skolen er ikke lenger kirkens, men statens, og skal formidle kunnskap om Luther, men har også mandat til å drøfte ham $\mathrm{i}$ forhold til verdier $\mathrm{i}$ Opplæringslovens §1 - dvs. at elevene kan lære $a v$ Luther, som forbilde eller motbilde. Hva kan da velges ut som vesentlig? Jeg tar utgangspunkt i to case som omfatter nettopp disse brukerinstansene. Den ene er fra $\emptyset$ stfold 1984, den andre fra Øst-Tyskland 1983. Den ene er fra skolen, den andre fra samfunnet.

\section{TO HISTORIER}

Høsten 1984 tok jeg PPU ved Halden lærerhøgskole. En dag skulle vi ha observasjonspraksis på 7. trinn. Tema var Luther, og jeg fulgte undervisningen i to klasser. I den ene fortalte læreren om Luthers liv, med dramatiske høydepunkt som riksdagen i Worms og bortførelsen til Wartburg. Etterpå fikk elevene tegne; det ble mye hester og borger. I den andre klassen åpnet læreren Luthers lille katekisme og leste de første to-tre budene med forklaringer. Så skrev han resten av budene på tavla, og elevene fikk lage resten av forklaringene selv. Resultatet ble tolkninger etter Luthers mal.

Den andre historien foregikk året før. Jeg var i DDR i forbindelse med 500-årsjubileet for Luthers fødsel - som falt sammen med hundreårsjubileet for Marx' død. Begge ble feiret. «Vi ærer Karl Marx gjennom våre gjerninger», lød parolen på store bannere. «Karl Marx lever i oss.» Og Luther var på plakater overalt. Men ble han æret som Marx, for sin rolle i 1983?

«Luther - ikke bare for kristne», konstaterte teologen Helmut Zeddies (Zeddies 1984:6), og de som stusset over at det ateistiske DDR kunne hylle en teologisk reform-ator, fikk svar fra formannen i statens jubileumskomité, partisjef Erich Honecker, som kalte Luther «en av det tyske folks største sønner» og «en av de viktigste humanistene som strebet etter 
en mer rettferdig verden». Han bidro til kulturell og sosial framgang, og DDR ville pleie alle progressive tradisjoner (Honecker 1980:11). ${ }^{3}$

Like fullt hadde det marxistiske Lutherbildet endret seg. Før lærte østtyske skolebarn at Thomas Müntzer var den virkelige reformasjonshelten, mens Luther forrådte de revolusjonære bøndene. En ny forståelse kom etter hvert til uttrykk, og i 1980 stiftet staten sin komité for 500-årsfeiringen av reformatorens fødsel. Man påpekte at Luther ville reformere tro og kirke, men kom til å utløse en «tidlig-borgerlig revolusjon» med langtrekkende sosiale følger. DDR-historikere og samfunnsforskere framholdt i skriftet Thesen über Martin Luther (1981) at Luther bare kunne begripes hvis man tok ham alvorlig som teolog. 1500-tallets pavekirke solgte avlatsbrev og drev forretning på frelse. Som tidas største føydalherre måtte den bli dødelig truet hvis noen rokket ved grunnlaget for makten. Det gjorde Luther. Teologien hadde lært ham at frelse oppnås ved tro, som er Guds gave og ingen ytelse.

Tesene mot avlatshandelen utløste en folkebevegelse som ikke begrenset seg til kirkelige reformkrav, men ville endre hele føydalordningen. Opprørske bønder påberopte seg Luther. Han ville ikke vite av voldelig revolusjon, men ble opphav til en kirke med et omfattende humanitært og pedagogisk program. «Alt i alt: Luthers sosiale og etiske forskrifter, som viser dype bånd til det alminnelige folk, fortjener vår aktelse også i dag» (Honecker 1980:14). Avgjørende var også hans bibeloversettelse, ifølge Engels et mektig våpen i hendene på plebeierbevegelsen (Honecker 1980:13), som sammen med Luthers egne bøker fikk varig innflytelse på tysk skriftspråk og litteratur.

Feiringen lot seg altså forsvare. Kongresser, utstillinger, bøker, tv-programmer, restaurering. Men Luther ble mer enn en historisk helt: Jubileet henvendte seg til samtida, med folkets velferd i fokus: «Hans arv er i trygge hender hos oss » (Honecker 1980:17).

Da staten stiftet sin jubileumskomité, ble biskop Werner Leich, formann i den alt eksisterende kirkelige komiteen, invitert. Luther kan verdsettes fra mange vinkler, fastslo Leich - men hans utgangspunkt var Guds ord. Derfor: «Hvis en evangelisk biskop i DDR vil tale om Martin Luther, da må og skal han tale om den Herre Luther ville tjene» (Leich 1980:21). Tema for kirkens feiring var Luthers forklaring til det første bud: «Vi skal frykte og elske Gud over alle ting og lite fullt og fast på ham. » Setningen berørte et luthersk kjernepunkt: Gud alene sikrer menneskets skjebne - men å erstatte egen sikkerhet med Guds kjennes risikabelt. Tillit krever mot. Brennpunkt i feiringen var derfor Vertrauen wagen - å våge tillit. På kirkedager med opptil 100.000 deltakere kunne kirken utfordre staten, med paroler som «Kontroll er bra, tillit er bedre» og «Kjærlighet kjenner ingen grenser; grenser kjenner ingen kjærlighet».

Så langt de to Luther-historiene, egentlig fire: to fra skolen, to fra samfunnet. Om to måter å undervise om Luther på, og to måter å feire ham på. Den første læreren formidlet historie, den andre hermeneutikk, begge med allmenn relevans (om man ikke ser forklaringsoppgaven som forkynnelse). DDR-staten underslo ikke Luthers

3 Sitatene fra Honecker og Leich er i min oversettelse, etter den engelske utgaven av foredragene ved den statlige jubileumskomiteens stiftelse. Om utviklingen i DDRs Luther-bruk, se Brinks 1998 og Zeddies 1984. Reportasje fra feiringen: Aas 1983. 
teologiske utgangspunkt, men legitimerte feiringen i de sosiale og kulturelle virkningene, som bekreftet det sosialistiske samfunnets verdier. Og kirken flyttet fokus fra Luther til Gud, men rekontekstualiserte Luthers teologiske poeng om tillit i gudsforholdet til et allment - og politisk prekært - poeng om mellommenneskelig tillit.

Den første læreren og staten festet seg ved ytre hendelser og virkninger; den andre læreren og kirken kanskje ved det Goethe kalte «alt det andre». Den første læreren talte om Luthers risiko; den andre tok en risiko ved à vise elevene tillit og la dem skrive selv. DDR-kirken levde i risiko og trengte tillit. Her gikk også en linje fra samtid til fortid: en parallellforskyvning fra å være kritisk og utsatt i en totalitær stat til å være kritisk og utsatt i en totalitær kirke for 500 år siden.

Luther fikk sitt kairos i bruk. Var aktualiseringene forankret $\mathrm{i}$ «selve kjernen»?

\section{ET SENTRUM}

Luthers ord til Erasmus trenger ikke leses som den definitive formulering av reformasjonens kjerne. Ut fra den religiøse, politiske og kulturelle og virkningshistorien er det legitimt å vektlegge noe mer og annet enn det han selv så som sentralt. Men det er grunn til å spørre om Luthers sentrum fortsatt er underkommunisert i forhold til «alle disse andre spørsmålene». Og i så fall: hvorfor?

Striden med Erasmus gjaldt den frie vilje - ikke i jordiske saker, men i forhold til frelse. For Erasmus er det selvsagt at mennesket har fri vilje til å ta imot Guds nåde, mens Luther i skriftet De servo arbitrio (Om den trellbundne viljen, 1525) hevder at den minste egenandel - om enn bare vilje - vil frata Gud æren for frelsen og gjøre men- nesket usikkert og selvsentrert.

Luthers logikk spisses ytterligere i disputasjonstesene De homine (Om mennesket, 1536). Her ser han mennesket i to perspektiv som ikke kan settes på samme formel: som ressursvesen i verden og som mottaker i relasjon til Gud - det filosofiske og det teologiske menneske. «Filosofien, som er den menneskelige visdom, definerer mennesket som et dyr utstyrt med fornuft, sanser og kropp», fastslår Luther anerkjennende. Men definisjonen gir ikke hele sannheten - den tilhører teologien: «Når Paulus i Rom. 3 (v. 28) sier: 'For vi mener at mennesket blir rettferdiggjort ved tro, uten gjerninger', gir han med ordene 'mennesket blir rettferdiggjort ved tro' en kortfattet definisjon av mennesket» (Luther 1983:335ff). Den siste definisjonen strider mot common sense, da den ikke sier noe om substansen til det den definerer. Det er også poenget. Skolastikken - og Erasmus - definerer mennesket forut for relasjonen Gud/menneske, som et vesen med fornuft og vilje. I det praktiske liv kan mennesket defineres slik. Men skal denne definisjonen gjelde i gudsforholdet, kan mennesket aldri være sikker på om det har brukt sine egenskaper godt nok - selv om det kun gjelder vilje.

Det teologiske menneske defineres antiessensialistisk, ved en handling utenfor det selv. Mennesket blir til idet Gud forholder seg til det. Det kan skape usikkerhet; man må oppgi kontrollen. Men også trygghet: Vår teologi er viss fordi den plasserer oss utenfor oss selv, sier Luther (Ebeling 1978:203). Ved per definisjon å frata mennesket alt potensial i gudsforholdet, er medmennesket sikret omsorg for sin egen skyld. Handlingene fratas religiøs funksjon; det er ikke Gud, men mennesker 
som trenger dem. Dette er grunnlaget for Luthers kallsetikk, en oppvurdering av det verdslige liv.

Erasmus' menneskesyn skulle imidlertid få større innflytelse enn Luthers. Vilje og valg fikk særlig appell i pietistisk omvendelseskristendom, en autonomi i harmoni med det moderne. Men Luther peker også fram mot modernitet og sekularisering: Hans umyndiggjøring av mennesket i gudsforholdet viser det bort fra religiøs grubling og frigjør det sekulære subjekt. Teologen Paul Tillich taler om protestantismens passion for the secular (Tillich 1987:88f). Men verdsliggjøringen er paradoksalt nok religiøst motivert. Luther-forskeren Gerhard Ebeling sier det slik: «Derfor trenger kjærligheten troen, fordi den er ren kjærlighet bare der hvor mennesket er blitt fratatt omsorgen for seg selv, takket være en fundamental visshet» (Ebeling 1978:135).

Ble Luthers sentrum realisert i DDR? Staten sto fjernt fra viljestriden, men ikke fra de sosiale følgene av en «passion for the secular». Kirken tematiserte tillit som teologisk og politisk relevant. Luther ble realisert i bruk. Det er en slik forståelse fagdidaktikken gir dekning for, forstått som kunnskap konstituert i bruk. Dette får følger for religionsdidaktikken, som tematiserer hva som er hermeneutisk og politisk legitim realisering av et faginnhold.

\section{FAGDIDAKTIKK}

Fagdidaktikk handler altså ikke bare om å formidle, men å legitimere og definere. Selv om forskningen er forbi slike forenklinger, tenker flere fortsatt dikotomisk: stoff/ metode, hva/hvordan, jf. universitetenes gamle skille mellom «rent» fag og praktisk-pedagogisk supplement. ${ }^{4}$ Men fagdidaktikken bryter opp denne todelingen på en måte som er berikende for faget selv. I tradisjonen fra Comenius spør den etter undervisningens hva, hvordan og hvorfor (Gundem 2008:5, Ongstad 2012:3). ${ }^{5}$ Og det siste, legitimeringsspørsmålet, er drivkraft både til å definere og formidle et innhold. Fagdidaktikk som forskningsfelt ble i stor grad drevet fram av spørsmålet om kunnskapens sosiale legitimering: «Kort kan fagdidaktikk sies å ta opp det enkelte fags egenart og funksjon i samfunnet, samt dets formidling på ulike nivå og i ulike sammenhenger - f.eks. i undervisningssituasjoner og i massemedia» (RHF/NAVFs skoleforskningskomité 1983, etter Ongstad 2004:37). ${ }^{6}$ Utfordringen ble «å foreta faglige valg og prioriteringer som er viktige for samtidens mennesker» (Lorentzen 1998:11).

Norskdidaktikeren Laila Aase gir en ambisiøs definisjon: «Fagdidaktikk er alle de refleksjoner en kan knytte til et fag og undervisning av dette faget, som kan gi $\emptyset \mathrm{kt}$ kunnskap om fagets beskaffenhet, om fagets legitimering og $\emptyset \mathrm{kt}$ kunnskap om hvordan faget kan læres, undervises og utvikles» (Aase i 1990, etter Ongstad 2004:51). Hun starter altså ikke i metodikkens hvordan, men i hva og hvorfor. Slik blir fagdidaktikk ikke et praktisk vedheng,

\footnotetext{
4 Frede Nielsen kaller den tradisjonelle universitets-todelingen et faglig-pedagogisk addisjons-spor, i motsetning til lærerskolenes integrasjons-spor (Nielsen 2012:15f).

5 Ongstad karakteriserer både forståelsen av fagdidaktikk som «fag pluss didaktikk» og «svaret på spørsmålsrekken fagets hva, hvordan og hvorfor» som to allmenndidaktiske stereotypier (en tredje er at forståelsen domineres av den didaktiske relasjonsmodellen). Jeg bruker likevel den andre stereotypien polemisk mot den første, da den synliggjør legitimeringsspørsmålets primat.

6 Jf. flere definisjoner hos Ongstad 2004:51ff.
} 
men noe overgripende og betydningsbærende. For å følge norskmetaforikken: Slik verb bøyes i bruk, blir fagdidaktikk faget i bruk, faget i finitt form.

Fagdidaktikeren Sigmund Ongstad framhever den definerende funksjonen: «[I] det $\emptyset$ yeblikk didaktikk ikke bare blir noe isolert som ligger utenfor faget eller fagkunnskapen, men noe dynamisk som virker inn på fagets hva, så siver det didaktiske inn i 'faget' og tenderer mot å restrukturere eller omdefinere det» (Ongstad 2004:34). Implisitt forankrer han fagdidaktikken i bruksaspektet, med henvisning til Paul Hernadi: «Idet en ytrer eller kommuniserer, utpeker en noe den andre bør rette oppmerksomheten mot og som ville forblitt ufokusert uten utpekingen. Det greske ordet for denne mest grunnleggende kommunikative funksjonen er nettopp deik, å utpeke» (Ongstad 2004:45). ${ }^{7}$

Fagdidaktikk er altså å utpeke et samfunnsrelevant sentrum - som også er fagets eller emnets mål. Det er i bruken emnet/faget er inkarnert. Og hvordan et innhold kan utpekes og realiseres i nye kontekster, ut fra ulike mandat, er et klassisk tema i religionsdidaktikken.

\section{RELIGIONSDIDAKTIKK}

Luther definerte sitt sentrum som striden om fri vilje i gudsforholdet. Kan dette rekontekstualiseres i et sekulært samfunn? I moderniteten oppsto spørsmålet om en religion fra fortida kunne gjøres mindre fremmed. Den kunne aktualiseres ved å fjerne det mytiske (1800-tallets kulturprotestantisme) eller ved å nytolke det (1900-tallets eksistensteologi). Kritikerne fryktet religion på mottakernes premisser. Biskop J.C. Heuch ironiserte over liberalteologen Lyder Bruns ønske om å komme alle i møte:

[Forkynneren] vilde da ligne en Tjener, som gaar omkring med et Bret, hvorpaa der er forskjellige Forfriskninger. En saadan vil jo sige: «Behager De Kaffe? Ikke? Eller maaske The? Heller ikke? Men Chokolade?» Paa samme Maade synes en saadan Forkynder at maatte have Noget at tilbyde hvert Trosstandpunkt. «Behager De en Prcediken om Guds Søns Død for våre Synder? Ikke? Eller maaske om Galilceas fromme Profet? Heller ikke? Men en ren ethisk Prcediken, den blotte Moral? Den vil kanske vakke Behag.» (Heuch 1902:103)

Liknende kritikk har vært reist mot retninger i nyere religionspedagogikk, godt illustrert i debatten om fortellingsdidaktikk. ${ }^{8}$ I pionerarbeidet I begynnelsen var fortellingen peker Halldis Breidlid og Tove Nicolaisen på et skille: Noen vektlegger at fortellinger må presenteres som del av en bestemt religiøs tradisjon, med klargjøring av opprinnelig kontekst. Andre vekter et allmennmenneskelig, eksistensielt nivå: «at alle, uansett religiøs eller ikkereligiøs bakgrunn, kan oppleve noe og lære

\footnotetext{
7 I en instruktiv artikkel om forholdet didaktikk/fagdidaktikk viser Bjørg Brandtzæg Gundem også til deik som å vise vei og avdekke: «Didaktikk var derfor kunsten å komme frem til noe som ikke var klart synlig eller lå opp i dagen for å bli oppdaget, observert og anerkjent» (Gundem 2008:5). Gundem påpeker fagdidaktikkens status som primær i vekselvirkningen med generell didaktikk. Den har gitt didaktikken en ny giv. «For det er i den fagdidaktiske kontekst den didaktiske refleksjon og handling foregår» (Gundem 2008:11)

8 Når jeg bruker debatten om dimensjonstenkning i fortellingsdidaktikken som inngang til en drøfting av troslæredidaktikk (noe som ikke er en selvfølge, med fortellingenes åpnere karakter som ulikt et dogmatisk læreinnhold), er det fordi den treffer det generelle spørsmålet om rekontekstualisering, som antydet med Heuch-sitatet og utdypet med eksemplet om aktualisering av vingårdslignelsen ut fra Luthers teologi.
} 
noe av alle fortellinger». For à strukturere tolkningsmangfoldet skiller de ut tre dimensjoner i fortellingene: en allmennmenneskelig, en (felles)religiøs og en religionsspesifikk (Breidlid og Nicolaisen 2012: 59ff). ${ }^{9}$ De viser til Michael Grimmitt og John Hull, som legger opp til at elever ikke primært skal lære om, men av religionene.

Vektlegging av det allmenne, og at alle kan lære av fortellingene, har møtt kritikk - begrunnet hermeneutisk ut fra ivaretakelse av fortellingenes intensjon, og politisk ut fra fagets mandat. I debatten som fulgte førsteutgaven av boka, framholdt Sidsel Lied at en fortelling presenterer en bestemt forståelse av virkeligheten og ikke er åpen for enhver tolkning:

Selvsagt må den allmenne dimensjonen ved fortellingene også holdes fram for eleven og dyrkes. Men da skal både vi og elevene vite hva vi gjør: at vi tar fortellingene ut av deres vanlige brukskontekst, nemlig religionenes og livssynenes verden, og plasserer dem inn i en annen, nemlig vår egen erfarings- og opplevelsesverden. Da endres [...] fortellingenes budskap. (Lied 2001:29)

I en historisk-kritisk lesning vil originalkonteksten legge rammer for en rekontekstualisering, mens en tekstintern tilnærming åpner andre tolkningsrom. Robert W. Kvalvaag viste til at Breidlid og Nicolaisen ikke var opptatt av sannheten bak fortellingen, men «sannheten $i$ fortellingen slik den oppleves av tilhørerne», noe de begrunnet med at skolekontekst er ulik religiøs kontekst: Da skolen ikke skal gi religiøs oppdragelse, er det naturlig å presentere fortellingene som åpne. ${ }^{10}$ Dette fant han problematisk ut fra fagets mandat om å presentere religioner $\mathrm{i}$ sin egenart (Kvalvaag 2001:162).

Et mål om å lære $a v$ religion er også er blitt kritisert ut fra skolens mandat. BengtOve Andreassen påpeker at man ifølge planene skal lære om religioner, med en religionsvitenskapelig tilnærming. I andre fag kan man også lære av, f.eks. lære likestilling av Et dukkehjem - men i religionsundervisning rammes dette av konvensjoner staten er forpliktet på, og kan komme i strid med religionsfriheten. At elevene får perspektiv på egen eksistens ved å lære om religioner og livssyn, kan ikke en lærer styre - men undervisning kan ikke ha som mål å lære av religioner (Andreassen 2016:125ff). Andreassens posisjon er diskuterbar og kan problematiseres som positivistisk (kunnskaps- og verdiformidling kan ikke sorteres så enkelt), ${ }^{11}$ men jeg forholder meg til den for å kunne prøve en Lutherrekontekstualisering mot allment definerte verdikriterier.

Hva så om en religionsspesifikk lesning motsier allmenne sannheter? Breidlid og Nicolaisen nevner lignelsen om arbeiderne i vingården, som făr lik lønn for ulikt arbeid (Matt. 20, 1-16). Å lese den religionsspesifikt om det kristne gudsbildet er ikke nødvendigvis problematisk, men spørsmålet er «hvorvidt etikken som slike lignelser formidler, kan være idealer for en verdslig etikk eller samfunnsmoral»

\footnotetext{
9 Det kan diskuteres i hvilken grad dimensjonsmodellen er et analytisk hjelperedskap for læreren, eller også skal aktiveres for eleven. Når det gjelder Luther, må hans teologiske poeng først presenteres i historisk kontekst (som kontroversielt), og ikke i utgangspunktet abstraheres til en allmenn sannhet (jf. nedenfor).

10 Kvalvaag viser til førsteutgaven av I begynnelsen var fortellingen, s. 10, tilsv. Breidlid og Nicolaisen 2011:11 (Kvalvaag 2001:160).

11 Man kunne endog hevde at en konsekvent sekulær tilnærming ikke ville særbehandle religionene negativt i forhold til andre kulturuttrykk som kilde til verdifundamentering. Jf. f.eks. sekulærhumanisten Corliss Lamonts anerkjennelse av evangeliene som etisk inspirasjon (Lamont 1988:49).
} 
(Breidlid og Nicolaisen 2011:436). Altså: Kan læreren gå fra om til $a v$ ?

Det gjør religionspedagogen Keld Skovmand m.fl. i sin aktualisering av lignelsen: Budskapet er ikke bare at Gud opererer med en annen målestokk enn mennesker, men en etisk appell om at mennesker seg imellom skal gjøre denne målestokken gjeldende:

Vanskeligheden ved at gøre det består $i$, at det radikale lighedskrav modsiger en meget vasentlig del af den menneskelige erfaring og flere af de principper, mennesket historisk set har lagt til grund for dannelsen af samfund: Vi har en forventning om, at vi belønnes for vores indsats, og at vi ikke får det samme, når vi har ydet forskelligt, [...]. Det er $f$ ex den logik, vi andser for at vare grundlceggende på arbejdsmarkedet, hvor princippet om noget-for-noget råder. (Skovmand ml.fl. 2008:77)

Poenget i lignelsen er altså kontraintuitivt, i strid med intuisjon og vanlig fornuft. Det kontraintuitive representerer en diskontinuitet mellom det religionsspesifikke og allmenne, og vil virke naturstridig, fremmed. Med Lowenthals skille: Det kan utforskes som history, men egner seg ikke som heritage.

Men hvis vingårdslignelsen skal vise gudsrikets annerledeshet, er det da hermeneutisk forsvarlig å gjøre den til modell for det jordiske? En slik problemstilling møter oss i Luther-didaktikken. Det er uproblematisk å undervise om reformasjonen og dens følger: religiøst, kulturelt, sosialt, politisk. Og Luthers autonomi- og individorientering vil intuitivt appellere til et moderne menneskesyn. Det er også prinsipielt uproblematisk (legitimt, men ikke lett) å undervise om det kontraintuitive $\mathrm{i}$
Luthers lære: det teologiske menneske og den trellbundne vilje. Det forutsetter kontekstbevissthet, at man ikke alminneliggjør det fremmede. Men kan man lære av det kontraintuitive?

\section{LUTHER - DIDAKTIKK}

«Skillet mellom å lære om og å lære $a v$ handler om hvilke kategorier vi kan tillate oss å være normative eller ideologiske i forhold til», påpeker Bengt-Ove Andreassen (Andreassen 2016:127). Ut fra Opplæringsloven ligger det nær å peke på menneskeverd og likeverd, nasjonal kulturarv så vel som kulturelt mangfold.

DDR-statens feiring inngikk i en tradisjon for å bruke Luther som nasjonal identitetsmarkør, som bl.a. historikeren Jan H. Brinks har dokumentert: På 1800-tallet kunne Luther bli identifisert med det germanske - avgrenset mot f.eks. det katolske og jødiske. Jubileet i 1917 ble dominert av nasjonal krigspropaganda, og nazistene spilte på Luthers antisemittisme. På 1950-tallet oppdaget DDR hans politiske verdi: statstroskap og arbeidsetikk. På 1980-tallet inngikk han i diskusjonen om kulturarv (Erbe und Tradition), og Brinks ser et motiv for 1983-markeringen i det å skape en nasjonal DDR-identitet avgrenset mot BRD (Brinks 1998:10). ${ }^{12}$ Identitetsmarkering via kulturarv er altså tvetydig. Som Lowenthal påpeker, blir kulturarv notorisk brukt til å skape skiller mot andre (Lowenthal 2015:502ff).

Før 500-årsjubileet i Norge har ikke staten annektert Luther, men overlatt markeringen til kirken. Tema er nåde, aktualisert som «Frelsen er ikke til salgs», «Mennesker er ikke til salgs» og «Skaperverket er ikke til salgs». Det første 
er spesifikt teologisk, mens menneskeverd og miljø er allmenne verdier tilkoplet ved gratis-begrepet, jf. det anti-kommersielle i tesene mot avlatshandelen.

Tarald Rasmussen viser til et bredere engasjement $\mathrm{i}$ andre land: I Danmark har statlige og kirkelige institusjoner gjort mye for å fremme forståelse av reformasjonens betydning for kirke og samfunn, dansk identitet og bevissthet, og i Tyskland har kirken gått sammen med politikere og forskere for å vise hvordan reformasjonen har bidratt til endring på en rekke samfunnsområder. Men det har stått strid om hva man skulle feire:

Noe av kritikken går på at man ikke kan fortsette å redusere reformasjonens betydning til det religiøse og snakke om «nåden» og «troen» med gamle teologiske formler. En slik teologisk isolasjon av reformasjonens relevans kommuniserer ofte dårlig både innenfor og utenfor kirken, og innebarer en devaluering av dens bredere historiske betydning. (Rasmussen 2016)

I Norge knytter man i mindre grad an til «reformasjonen som historisk hendelse og teologisk prosjekt», og unngår vanskelige temaer som Luthers jødehat. Som en årsak til den manglende kultur- og samfunnsorienteringen peker han på at Norge mangler en historisk kopling av reformasjon og nasjon; reformasjonen innledet nedgang og dansketid. I Sverige, Danmark og Tyskland kan allmennhistorikere framheve ikke-religiøse gevinster, mens reformasjonen i Norge er overlatt kirken og teologene, dermed det indrereligiøse med Luther og nåden i sentrum (Rasmussen 2016).

Men også i Norge er Luther meldt inn i samfunnsdebatten. Marius Timmann Mjaaland mener han ofte er misforstått: Luther blir gjerne sitert som teologisk reformator, men var også politisk dissident. I boka The Hidden God leser Mjaaland ham som filosof, politisk tenker og frihetstenker. ${ }^{13}$ Poenget er et nytt perspektiv på mennesket: Verdighet og betydning ligger ikke i hva det gjør, men hva det er: et menneske som har fătt livet i gave. Altså et oppgjør med en $\emptyset$ konomisk tenkemåte og «en radikal oppvurdering av det enkelte menneske, som umiddelbart fikk politiske konsekvenser - og kulminerte i politiske katastrofer» (Mjaaland 2016b).

Hvordan kan så Luthers teologi inspirere samfunnstenkning, når han sekulariserte makten og skilte religion og politikk? Her er vi tilbake ved vingårdslignelsen, som Skovmand m.fl. forfølger nettopp via Luther: «Overfor Gud er mennesket intet, og denne grundtanke ligestiller alle: Ligeværd bliver begrundet i intetværd.» Men Luther overfører ikke likheten til samfunnet. Og han tar avstand fra å omsette evangeliet til politikk, noe som skjedde både i den katolske kirke og i bondeopprøret (Skovmand m.fl. 2008:78).

Kallstanken som flytter fokus fra det religiøse til det verdslige, er imidlertid avgjørende for sekulariseringen. Og velferdsstaten som gir ytelser uavhengig av evne, har røtter i reformasjonen: «Som vi så, var det ret nøje sammenhæng mellem lignelsens retfærdighedsprincip og Luthers retfærdigg ørelseslære. [...] Der er tilsvarende en ret tydelig sammenhæng mellem Luthers retfærdiggørelseslære og den universalistiske velfærdsstat.» Men så et poeng: 
Det princip, der hos Luther gjaldt troen, er kommet til at galde en vasentlig del af selve samfundsindretningen. Hvor troen hos Luther vedrører forholdet mellem menneske og Gud, handler ydelserne $i$ velfordssamfunnet om forholdet mellem borgerne og staten. Begge steder goelder nådeprincippet. (Skovmand m.fl. 2008:92f)

Er dette noe elever kan lære $a v$ ? Det burde ikke være problematisk å framheve modellen som positiv, da menneskeverd og likeverd er verdier i Opplæringsloven. Men mennesket uten ytelse er hos Luther det teologiske menneske, i gudsforholdet. Det filosofiske menneske er ikke ressursløst, men handlekraftig. En antropologi som ensidig vekter menneskets «intetværd», er ikke luthersk - men den bekrefter et bilde av lutherdom som mørk og livsfornektende.

\section{Det kontraintuitive}

Luthers frustrasjon over at bare Erasmus har skjønt hva striden står om, kan ses i dette perspektivet. En lære om manglende viljefrihet er kontraintuitiv, i strid med både skolastikken og et moderne humanistisk menneskesyn. Som påpekt av Inge Lønning: «Selv de ivrigste lutheranere har følt seg ille til mote ved det man har ansett for et ekstremt antropologisk standpunkt, og i store deler av den lutherske forkynnelses- og fromhetstradisjon har i virkeligheten Erasmus' standpunkt stått sterkere enn Luthers » (Lønning 1981:116).

Det kontraintuitive er uanskuelig og krever intellektuell abstraksjon. Når mennesket ses i to perspektiver, kan det ikke fanges i ett blikk. Forenkling blir fortegning: Hvis det teologiske menneskes passivitet overføres til samfunnet, styr- kes myten om det mørke lutherske - like uluthersk som å la det filosofiske menneske innta gudsforholdet som religiøs aktør med vilje og valg.

Må man da nøye seg med å lære om Luthers teologiske menneske som en historisk kuriositet, eller kan man ut fra samfunnets behov og skolens verdiformidlingsmandat forsvare å lære $a v$ det?

Inge Lønning hevder at Luthers bestemmelse av forholdet mellom det filosofiske og det teologiske menneske ikke har tapt sin aktualitet: «<Kontrasten mellom de to menneskedefinisjoner er det livsviktig å holde fast i en kultur hvor vi som aldri før i historien dyrker mennesket som kapasitet, som bevissthetsressurser, som selvutfoldelse.»

Det er ganske sikkert uvant for oss å lese Paulus' utsagn i Rom. 3,28 som en definisjon av mennesket, men mon ikke Luther har rett $i$ at apostelens «ikke ved lovgjerninger» er et bolverk om menneskeverdet? Talen om mennesket som blir rettferdiggjort av Guds nåde alene ved troen på Jesus Kristus alene plasserer menneskeverdet det eneste sted hvor det kan forbli uantastet av alle våre ressursog utfoldelsesmålestokker. Min verdighet som menneske er en fremmed verdighet, uavhengig av min livsskjebne og livsinnsats. (Lønning 1976:45)

Altså en manifestering av menneskeverd og likeverd. «Men det er en menneskekunnskap som på en helt avgjørende måte henger sammen med den kristne kunnskap om Gud slik Han har åpenbart seg i Jesus», fortsetter Lønning. Kan da en slik kunnskap formidles som allmenn norm?

I skolen er utgangspunktet å lære om religion. Luthers sentrum må presenteres $\mathrm{i}$ 
sin originale religiøse kontekst. Elever som ikke kan dele den teologiske begrunnelsen, bør ikke lære $a v$ religion ved sømløst å få presentert Luthers teologiske menneske som støtte til verdier i Opplæringsloven. Men en kontekstbasert profilering av Luthers uvante poeng vil gi «om»-kunnskap som kan utfordre til selvstendig verdirefleksjon: Det er mulig å tenke annerledes om mennesket enn vi normalt gjør i vårt samfunn.

Et beslektet poeng er at protestantismens passion for the secular paradoksalt hviler på religion: Tro frigjør til kjærlighet. Luthers løsning av et teologisk problem får sekulære følger. Men at kjærlighet trenger tro for å være ren kjærlighet, slik Ebeling formulerer det, er kontraintuitivt. Når Luther stilte et religiøst spørsmål - kan da en faglig forsvarlig rekontekstualisering bli annet enn en eksklusiv henvendelse til de religiøse? Er befrielse fra religiøs streben relevant $i$ et sekulært samfunn?

I en kultur som synes å motsi sosiologiens tradisjonelle sekulariseringshypotese, bør man ikke avvise Luthers teologiske premisser som irrelevante. Ut fra disse legitimeres en nødvendig verdslig rasjonalitet. Men er hans teologiske basis relevant for dem som ikke trenger befrielse fra religion?

\section{To BRUK?}

Blant Luthers mange dikotomier - som samsvarer med dobbeltperspektivet i De homine - er den dobbelte bruk av Loven: politisk og åndelig. Har vi en tilsvarende bruk av Luther?

Det er tradisjon for en allmenn, «politisk» Luther-bruk, ut fra hans anerkjennelse av det verdsliges autonomi. DDR-staten feiret kultur og velferd, uten Luthers teologiske begrunnelse for verds- ligheten. Luther som kulturarv er også problematisk. Han har vært lite brukt til norsk nasjonsbygging, men «kristen kulturarv» knyttes i dag til en politisk agenda (Døving og Kraft 2013:88ff). Med kategoriene fra fortellingsdidaktikken: Man bør ikke identifisere det allmenne med det nasjonale.

Men er ikke Luthers «åndelige bruk», som gjelder menneskesynet i gudsrelasjonen, enda mer ekskluderende? Hvis Luthers poeng er at tro frigjør til kjærlighet - kan det allmenngjøres uten å tale om tro? DDRs jubileumskomité underslo ikke Luther som teolog - men, som påpekt av Brinks: «His dualism was not, or was hardly, brought up for discussion» (Brinks 1998:9). Kirken fremmet imidlertid tillitens vågemot som samfunnsrelevant - uten å kreve tilslutning til den teologiske basis.

Luthers lære om det teologiske menneske utfordrer kulturarv-begrepet; den er anti-essensialistisk og dyrker ikke en substans som kan hevdes som eksklusiv arv og identitet. Mennesket er definert som mottaker. «Vi er tiggere, det er sant» var visstnok Luthers siste skrevne ord - og det var biskop Leichs første ord til DDRs jubileumskomité (Leich 1980:22). Det kontraintuitive hos Luther er at egenskaper - individuelle og kollektive identitetsmarkører - ikke begrunner verdi, dermed heller ikke merverdi. Slik kan - og bør Luthers teologiske sentrum rekontekstualiseres som allment relevant, forankret i verdier som menneskeverd og likeverd. Men bare når poenget presenteres i sin historiske debattkontekst (lære om), blir det mulig å forstå dets kontraintuitive og «fremmede» karakter, som også etter 500 år kan utfordre common sense-oppfatninger av verdi som kvalitet og ytelse (lære $a v$ ).

En rekontekstualisering betyr ikke at 
vi reduserer Luther til en skjerm å projisere våre verdier på. En fagdidaktiker må arbeide hermeneutisk, bevisst om at historisk erkjennelse er en dialogisk prosess der vi bringer med oss vår tids interesser, samtidig som vi lar oss tiltale av det fortidige og fremmede.

\section{LITTERATUR}

Andreassen, Bengt-Ove. [2012] 2016. Religionsdidaktikk. En innføring, 2. utgave. Oslo: Universitetsforlaget.

Breidlid, Halldis og Tove Nicolaisen. [2000] 2011. I begynnelsen var fortellingen, 2. utgave. Oslo: Universitetsforlaget.

Brinks, Jan Herman. 1998. «Luther and the German state». The Heythrop Journal. Vol 39, Issue 1, s. 1-17. [online] Tilgjengelig: http://onlinelibrary.wiley. com/doi/10.1111/1468-2265.00062/pdf [21. august 2016]

Døving, Cora Alexa og Siv Ellen Kraft. 2013. Religion ipressen. Oslo: Universitetsforlaget. Ebeling, Gerhard. [1964] 1978. Luther. En innføring i hans tenkning. Oslo: Gyldendal.

Eriksen, Anne. 2009. «Kulturarv og kulturarvinger» i Nytt Norsk Tidsskrift nr. 3-4, s. $474-480$.

Gundem, Bjørg Brandtzæg. 2008. «Didaktikk - fagdidaktikk, anstrengte eller fruktbare forhold? 》 i Acta Didactica Norge. Vol. 2, nr. 1, s. 1-15.

Heuch, J.C. 1902. Mod Strømmen. Kristiania: Aschehoug.

Honecker, Erich. 1980. «Our times call for commitment to progress, reason and humanity» i Martin Luther and our age. Constituent meeting of the GDR Martin Luther Committee, Berlin, 13 June 1980. Dresden: Verlag Zeit im Bild, s. 9-17.

Kvalvaag, Robert W. 2001. «Det strukturalistiske fortellingsunivers. En kommentar til boka 'I begynnelsen var fortellingen' av Halldis Breidlid og Tove Nicolaisen». Prismet nr. 4, s. 160-166.

Lamont, Corliss [1982] 1988. Det humanistiske livssyn. Oslo: Universitetsforlaget.

Leich, Werner. 1980. «Linked to us all in the search for the meaning of life» i Martin Luther and our age. Constituent meeting of the GDR Martin Luther Committee, Berlin, 13 June 1980. Dresden: Verlag Zeit im Bild, s. 19-27.

Lied, Sidsel. 2001. «Tolkning og bruk av religionenes og livssynenes fortellinger» $\mathrm{i}$ Religion og Livssyn nr. 3, s. 25-31.

Lorentzen, Svein m.fl. 1998. Fagdidaktikk. Innføring i fagdidaktikkens forutsetninger og utvikling. Oslo: Universitetsforlaget.

Lowenthal, David. [1986] 2015 The Past is a Foreign Country - Revisited. Cambridge: Cambridge UP.

Luther, Martin [1536] 1983: «Disputasjon ved D. Martin Luther: Om mennesket» i Verker i utvalg bd. VI. Oslo: Gyldendal, s. 335-337.

Luther, Martin [1525] 1981: «Om den trellbundne viljen» i Verker i utvalg bd. IV. Oslo: Gyldendal, s. 117-352.

Lønning, Inge. 1976. «'Det teologiske menneske'. Om den kristne menneskekunnskap» i Kirke og kultur nr. 1. s. 42-46.

Lønning, Inge. 1981. «Innledning» [til «Om den trellbundne viljen»] i Luther, Martin: Verker $i$ utvalg bd. IV. Oslo: Gyldendal, s. 113-117.

Mjaaland, Marius Timmann. 2016a. The Hidden God. Luther, Philosophy, and Political Theology, Bloomington og Indianapolis: Indiana University Press.

Mjaaland, Marius Timmann. 2016b. «Alle revolusjoners far» i Klassekampen 16.02.

Nielsen, Frede V. 2012. «Fagdidaktik som integrativt reaktionsfelt» i Sammenlignende fagdidaktik 2, Cursiv nr. 9, s. 11-32.

Ongstad, Sigmund. 2004. «Fagdidaktikk som 
forskningsfelt» i Kunnskapsstatus for forskningsprogrammet KUPP (Kunnskapsutvikling $i$ profesjonsutdanning og profesjonsutøving), Oslo: Norges forskningsråd, s. 30-53. [online] Tilgjengelig: http:// www.forskningsradet.no/csstorage/flex attachment/Rapport_om_kunnskapsstatus_kupp.pdf [21. august 2016].

Ongstad, Sigmund. 2012. «Fra kunnskap, via kontekst, kjerne og komparasjon til kommunikasjon. En fagdidaktisk utviklingslinje?» i Nordidactica nr. 1, s. 1-25.

Rasmussen, Tarald. 2016. «Nedslående plan for Luther-feiring» i Vårt Land 11.04. [online] Tilgjengelig: http://www.verdidebatt.no/debatt/cat12/subcat13/ thread11637426/\#post_11637533 [21. august 2016].

Skovmand, Keld, Lakshmi Sigurdsson og Robin May Schott. 2008. «Medborgerskabets værdidilemmaer» i Ove Korsgaard, Lakshmi Sigurdsson og Keld Skovmand (red.): Medborgerskab - et nyt dannelsesideal. Fredriksberg: RPF -Religionspædagogisk Forlag.

Tillich, Paul. 1987. On Art and Architecture. New York: Crossroad.

Zeddies, Helmut. 1984. «Luther, Staat und Kirche. Das Lutherjahr 1983 in der DDR.» Augsburger Universitätsreden 2. Augsburg: Augsburg Universität. [online] Tilgjengelig: http://www.presse.uniaugsburg.de/publikationen/unireden/ unireden_pdfs/UR_02_Zeddies1984_ Luther.pdf [21. august 2016].

Ågotnes, Hans-Jakob. 2008. «Kulturarv og kulturelt mangfald. 'Heritage studies' som internasjonalt forskingsfelt.» Foredrag i regi av prosjektet «Kulturarv, forsking og formidling», Lillehammer 2007. Publisert 15.10.08. [online] Tilgjengelig: http://kaff. ra.no/kaff/Kulturarv\%200g\%2okulturelt\%20mangfald.pdf [21. august 2016].

Aas, Per Anders. 1983. «Luther i DDR: En arv for kamerater og brødre» i Programbladet nr. 40, s. 38-39/59. 